\title{
Regional Origin Outperforms All Other Sustainability Characteristics in Consumer Price Premiums for Honey: Empirical Evidence for Germany
}

\author{
Katharina Bissinger ${ }^{1+}$ and Roland Herrmann ${ }^{1}$ \\ ${ }^{1}$ Justus-Liebig-Universität Giessen, Germany
}

\begin{abstract}
Sustainability and online retailing are two of the main challenges in the food industry. This study analyzes how honey characteristics, including sustainability indicators, affect consumer prices for honey, using 241 German honey prices in online and offline retailing. Many honey characteristics significantly influence honey prices. However, a clear identification of the regional origin of honey has a particularly strong impact on the consumer price premium. It outperforms all other sustainability indicators such as fairtrade certification, organic production, and environmentally friendly packaging. Regional origins that receive high relative and absolute consumer price premiums are Germany and German regions as well as individual EU and non-EU countries that have a reputation for high-quality in the honey market. Given this evidence, the major demand-side argument behind high consumer price premiums for defined origins appears to be food-safety related concerns. Thus, foreign suppliers will gain from international honey trade with Germany in different ways, depending on their reputation for quality. The magnitude of price premiums is surprisingly stable across different years, as are online prices of honeys that belong to the "core" assortment. Changes in the depth of the assortment, such as non-price competition, rather than price adjustments clear the market.
\end{abstract}

Keywords: Fairtrade, Hedonic Price Analysis, Origin, Organic Production

JEL Classifications: Q13, L15, L66

Received 19 July 2019, Revised 8 June 2020, Accepted 12 October 2020

\section{Introduction}

The European Union (EU) is the second-largest producer of honey worldwide. Thus, beekeeping is an essential component in the agricultural sector. In 2018, the major producers of honey in the EU were Romania, Spain, Germany, Hungary, Italy, and Poland. However, the trade balance for the EU is negative. It had a self-sufficiency ratio of $56 \%$ in 2018 and nearly $40 \%$ of the EU imports from third countries were covered by China (European Commission, 2020). Although the largest growth rate in the number of beekeepers has been in Germany since 2011,

\footnotetext{
+Corresponding Author: Katharina Bissinger

Ph.D., Institute of Agricultural Policy and Market Research, Justus-Liebig-Universität Giessen, Senckenbergstraße 3, Germany, Email: Katharina.M.Bissinger@agrar.uni-giessen.de

Co-Author: Roland Herrmann

Professor, Institute of Agricultural Policy and Market Research, Justus-Liebig-Universität Giessen, Senckenbergstraße

3, Germany, Email: Roland.Herrmann@agrar.uni-giessen.de
} 
Germany remained the largest importer in the EU with a self-sufficiency ratio of $48 \%$ in 2018. German imports are diversified with honey from nearly 50 countries. There is a substantial intra-EU share but other non-EU countries, e.g. Argentina (15.0\%), Mexico (14.7\%), and Ukraine (12.9\%), exceed China's share (4.5\% in 2017) in tons by far (FAO, 2020b). Consequently, the German honey market is characterized by many different honeys, originating from all over the world and consisting of a broad variety of different product characteristics. ${ }^{1}$

As sustainable production and consumption have become important issues in the food market, we are particularly interested in the sustainability characteristics of honey and whether these lead to consumer price premiums. There is strong evidence in the recent literature for the geographical origin (Lans et al., 2001), regional and organic production (Adalja, 2015; Cranfield et al., 2009), fairtrade certification (Pelsmacker et al., 2005), and combinations of several of these criteria (Didier \& Lucie, 2008) determining consumer's marginal willingness to pay for individual foods and, thus, consumers' buying decisions. All these characteristics are associated with the sustainability of food production and/or food consumption and can be interpreted as sustainability characteristics. In developed countries' markets for honey, all these sustainability characteristics occur in various forms, and competition between these markets is possible.

The importance of sustainability for food consumption has increased for honey. In a study on the U.S. retail demand for honey, Unnevehr and Gouzou (1998) showed that the honey market in the 1990s was already a modern agricultural market, as described by Sexton (2013). In this highly differentiated market, consumers paid substantial premiums for certain kinds of honey, "based on form, container, brand, and floral source" (Unnevehr and Gouzou, 1998: 49). In a comparison of honey sources, unique monofloral sources were associated with the highest price premiums. Although the authors present evidence of a higher marginal willingness to pay for several special characteristics of honey, sustainability characteristics had not yet played a role. In some later studies, that picture changed. Wu et al. (2015) found that the U.S. consumers have an additional willingness to pay for honey that is produced locally rather than domestically or internationally. They explained this with consumers' perceptions of health and environmental benefits of local honey. The study was based on experimental auctions. Local as well as organic honey appear to be significant in terms of consumer preferences and willingness to pay in other countries, too, as survey-based studies for Italy (Cosmina et al., 2016) and Denmark (Jensen and Mørkbak, 2013) revealed. The authors used choice experiments and multinomial logit choice modeling, respectively. Related recent work for Germany also exists. Bissinger et al. (2019) analyzed price premiums for honey characteristics at the retail level of the German online market for honey. The authors included various sustainability characteristics, such as organic production, type of packaging, fairtrade certification, and various indicators of regional production. The main conclusions were that implicit prices of sustainability are often positive but vary strongly, and that the consumer price premiums of regionality were 
high. Although these results on the German honey market are already interesting, they raise some important questions:

(i) The study by Bissinger et al. utilized online data for 2015 from an earlier report by Krandick (2015). The question on whether those findings are similar to, and representative of, the much larger offline market arises.

(ii) Honey supply from various regional sources varies over time. Shifts in honey supply occur in a non-uniform way due to differential weather conditions, bee diseases, and others. Therefore, implicit prices of sustainability may also vary over time.

(iii) Regionality, which appears to be a very important driver of a high retail price premium, may be a sustainability indicator if environmental concerns dominate preferences for regionally produced honey. However, there could be other reasons, too. First, preferences for food from their own region may result from the intention of consumers to support agriculture in their region. Second, consumers may (just) be interested in a clear description of the origin of honey as certain countries of origin are preferred. Honey with a defined origin and good reputation could lead to a price markup. A blend of honeys originating in different nations might induce a markdown.

Given this background, the objective of this article is to explain honey prices against honey characteristics and to explore, in particular, to what extent sustainability characteristics in honeys yield a consumer price premium. We apply a hedonic modeling approach, as Unnevehr and Gouzou (1998) and Bissinger et al. (2019) did. The advantage of hedonic analysis compared to consumer surveys is that (i) real market data are utilized and (ii) supply and demand factors determine the implicit price and the marginal willingness to pay for product characteristics. We deviate from Bissinger et al. (2019) by using more recent data that are not based on online prices alone. Moreover, we investigate whether the choice of a certain period affects the implicit prices of sustainability characteristics. Given the high price premium for regional honeys, we also discuss whether sustainability concerns are the main reason for price markups.

The article is structured as follows. Section II presents a theoretical model of the consumer premium for a sustainability characteristic on a market with two segments: (i) the conventional food and (ii) a food with one sustainability characteristic. The empirical model is introduced and the database is described in Section III. The empirical results are provided in Section IV, and the discussion of the results follows in Section V. Finally, the findings are summarized and conclusions are drawn in Section VI.

\section{Theoretical Background}

We use a highly stylized model to show how market segmentation for a food with a 
sustainability characteristic may arise in a formerly uniform conventional market. Figure 1 illustrates the model.

A competitive market is postulated, in which supply of the conventional food is represented by a market supply function $S$ and demand by a market demand function $D$. The equilibrium price for the conventional food is $p_{o}$.

Figure 1. Market segmentation with sustainability characteristics and the consumer and producer price premium

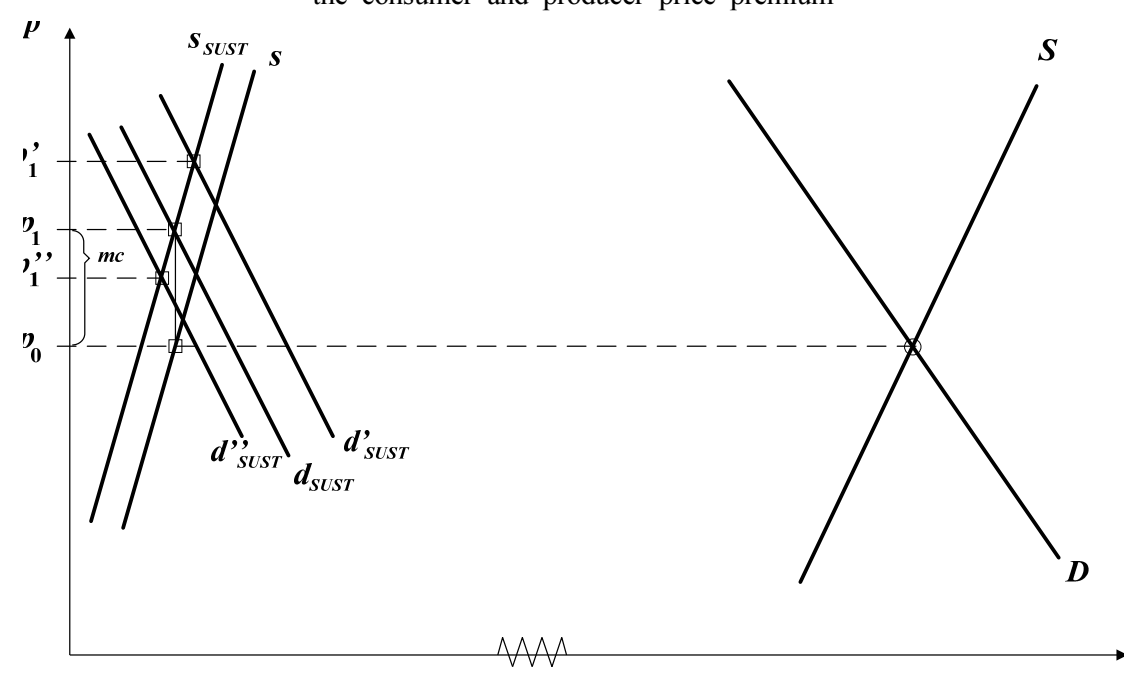

(Source) Authors' illustration.

Suppose that a small fraction of producers now switch to the production of a differential quality, that is, the food with a sustainable characteristic such as ecological production, fairtrade, or local or regional foods with a protected geographical origin. The sustainable food will reach, at least initially, a tiny market niche so that the market price of conventional food is unaffected. We indicate this by the interruption of the horizontal axis. Quantities on the mass market are, by assumption, very high compared to the niche market. The fraction of switching producers had initially a marginal cost function $s$. Switching to the sustainable product will raise marginal costs of production and marketing from $s$ to $s_{S U S T}$. This may be induced by stricter production standards that raise production costs. Ecological production is regulated by a harmonized standard in the EU. It may also be due to costs of advertising or the protection of the sustainability labels to which producers have to contribute, as in the case of protected geographical indications or fairtrade.

A pre-condition for a higher consumer price of the sustainable compared to the conventional food is that demand for sustainable food intersects the supply function $\left(s_{\text {SUST }}\right)$ above $p_{0}$. This situation is given for all three alternative demand functions that are shown in Figure 1. The 
vertical distance between the supply curves $s_{S U S T}$ and $s$ indicates the additional marginal costs of producers who switch to sustainable production. These additional marginal costs $m c$ are exactly covered when the demand curve $d_{S U S T}$ holds for the product with the sustainability characteristic. Furthermore, the price premium compared to the conventional product equals exactly the additional marginal costs of producing and marketing the sustainable alternative. Please note here that the supply and demand framework allows the consumer and producer premiums to be distinguished. At $p_{1}$, there is a consumer price premium $\left(p_{1}-p_{0}\right)$. The net producer price, however, is identical to the original situation: $p_{0}$. Switching to the production of the sustainable variety would not pay for producers. They would be indifferent toward the two options if switching costs are ignored. Demand for the sustainable alternative should be higher than $d_{S U S T}$ to induce a producer price premium from sustainable production. In the case of higher demand for sustainable food $\left(d_{S U S T}^{\prime}\right)$, a higher price $p^{\prime}$ would occur. The consumer price premium would be $\left(p_{1}^{\prime}-p_{0}\right)$, and the corresponding producer price premium would now be positive, too: $\left(p_{1}^{\prime}-p_{0}-m c\right)>0$. Switching to the sustainable product would pay for producers. With the alternative demand curve $\left(d_{\text {SUST }}^{\prime \prime}\right)$, the price of the sustainable product would be $p_{1}^{\prime \prime}$. A positive consumer price premium would still exist: $\left(p_{1}^{\prime \prime}-p_{0}\right)$. However, it would be associated with a negative producer price premium: $\left(p_{1}^{\prime \prime}-p_{0}-m c\right)<0$. Although the price of the sustainable product is higher than that of the conventional product, the price difference does not cover the additional marginal costs of producing the sustainable alternative. If $\dot{d}_{S U S T}$ remains as the medium- or long-run demand curve, switching to the sustainable alternative is not attractive for producers.

We can generalize from the theoretical model:

(i) A rising consumer price premium can be expected with a higher demand for the sustainability characteristic, ceteris-paribus.

(ii) The higher the marginal costs of producing the sustainability characteristic, the more the demand will have to grow to make the production of the sustainable food profitable.

(iii) If a consumer price premium, defined as the difference between the sustainable and the traditional food, persists over time, we can conclude that the consumer price premium involves a producer price premium. Otherwise, producers would produce the conventional alternative under profit maximization.

For empirical analysis, it is important to choose a supply and demand model that is based on actual market data and incorporates the consumers' marginal willingness to pay for the sustainability characteristic as well as marginal costs of its production and marketing. We will start from hedonic pricing analysis in the following empirical application and concentrate on the price premium for sustainability characteristics at the consumer market for honey in Germany. 


\section{Empirical Model and Data}

\section{A. The empirical model}

The empirical model is based on hedonic price analysis. While pure consumer studies with surveys or experimental techniques rest on the hypothetical willingness of consumers to pay for product characteristics, hedonic price analysis is based on observed market data. As was shown in the seminal contribution by Rosen (1974), implicit prices of product characteristics are driven by the demand for and supply of those characteristics.

The subsequent analysis follows earlier work in two important points. First, several alternative functional forms were estimated and compared. The log-linear specification, which is the most widely used function in the literature on hedonic analysis, fitted the data best, and provided plausible and robust results. It will be presented in the following section. Second, it is not possible to estimate demand coefficients from the hedonic model and, thus, derive actual willingness to pay from a demand function. Our data include price, but not quantity information. Therefore, the analysis concentrates on the reduced form of a market model in which actual prices represent market equilibria and are explained by supply and demand shifters, like in hedonic price analyses for other food markets (e.g., Schollenberg, 2012; Schröck, 2014).

The empirical model is as follows:

$$
\operatorname{In}\left(p_{i}\right)=a_{i}+\sum_{j=1}^{5} b_{j}^{*} V_{j i}+\sum_{k=1}^{14} c_{k}^{*} P C_{k i}+\sum_{l=1}^{17} d_{l}^{*} S C_{l i}+u_{i}
$$

where the natural logarithm of the price of honey in Euros per 500 grams $\left(p_{1}\right)$ is a function of vectors for vendors $(V)$, product characteristics $(P C)$, and sustainability characteristics $(S C)$. The vector of sustainability characteristics is:

$$
\sum_{l=1}^{17} d_{l}{ }^{*} S C_{l i}=\sum_{l=1}^{2} d_{l}^{*} \text { organic }_{l i}+\sum_{l=3}^{4} d_{l} \text { fairtrade }_{l i}+\sum_{l=5}^{6} d_{l} \text { packaging }_{l i}+\sum_{l=7}^{17} d_{l} \text { origin }_{l i}
$$

Equation (2) is self-explanatory. More detailed information about the variables behind each vector in Equation (1) and Equation (2) is depicted in Table 1. 
Table 1. List and Description of the Variables Behind Each Vector

\begin{tabular}{ll}
\hline \multicolumn{1}{c}{ Variables } & \multicolumn{1}{c}{ Description } \\
\hline Price & In $€ / 500 g$ \\
\hline Quantity & $\ln ($ gram $)$ \\
\hline Vendors ${ }^{\text {a) }}$ & \\
\multicolumn{1}{c}{ Gourmondo } & Online retailer, specialty shop \\
Alnatura & Multi-channel retailer, specialty shops for organic foodstuffs \\
Heimathonig & German online retailer for honey \\
myTime & Multi-channel retailer, supermarket \\
Rewe Center & Stationary market, supermarket \\
\hline
\end{tabular}

\section{Brand}

$D I B$

Deutscher Imkerbund, a cooperation of German apiculturists. Main aims: Exchange of technical know-how, retail of locally produced honey in food retailing (DIB 2019).

Individual Beekeeper Individual beekeepers are not part of a cooperation with other apiculturists and sell their products mostly via Heimathonig.de and weekly markets.

Private Label The variable refers to honey that is traded under a retailer's brand.

\begin{tabular}{ll}
\hline Multipack & More than one jar of honey (different sorts), for instance, is sold as one unit. \\
\hline Additives & The honey is refined by special ingredients, like cinnamon, nuts, cardamom. \\
\hline Extraction Method &
\end{tabular}

Standard

Others

For a detailed description of honey extraction methods, see FAO (2020a).

\begin{tabular}{c}
\hline Consistency \\
Creamy \\
Liquid \\
Others \\
\hline
\end{tabular}

\begin{tabular}{ll}
\hline Type & Honey made of the pollen from different blossoms. \\
Blossom Blend & Honey made of pollen only from heather. \\
Heather & Honey made of pollen only from rape. \\
Rape & Honey made of pollen only from fir. \\
Fir &
\end{tabular}

Other Monofloral Blossom Honey made of the pollen from one specific blossom (other than heather, rape and fir).

Exotic Honey made of pollen of exotic plants, like eucalyptus.

\begin{tabular}{cl}
\hline Fairtrade Certification & Organization imports fairtrade products to Germany. \\
GEPA & Main criteria: Support of disadvantaged producers in the Global South; change trade policy \\
GEPA $^{\circ}$ & through lobbying; motivate consumers to change buying behavior (GEPA 2020).
\end{tabular}

Fairtrade International

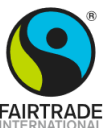

Fairtrade International organization that certifies producers in the Global South if specific economic, social and ecological standards are fulfilled. Aim: Improve situations of producers in the Global South (Fairtrade International 2020). 
Table 1. Continued

\begin{tabular}{|c|c|}
\hline Variables & Description \\
\hline \multicolumn{2}{|l|}{ Organic Certification } \\
\hline$\frac{\text { Bio-EU }}{\star^{* * *}+*^{* *}}$ & $\begin{array}{l}\text { The label introduced by the EU. Labeling of all packaged foodstuffs that are organically } \\
\text { produced in the EU (compulsory). Organic foodstuff originating in non-EU countries could } \\
\text { be (voluntarily) labeled with the Bio-EU label (BMEL 2020). }\end{array}$ \\
\hline $\begin{array}{l}\text { Bioland } \\
\text { Bioland }\end{array}$ & $\begin{array}{l}\text { The biggest cooperation of organic farmers, beekeepers, winemakers, etc. in Germany. } \\
\text { Main criteria: Circular economy, improve soil fertility, animal welfare, quality of food } \\
\text { products, support biodiversity, guarantee likelihood, future-oriented (Bioland 2020). }\end{array}$ \\
\hline \multicolumn{2}{|l|}{ Origin } \\
\hline \multicolumn{2}{|l|}{ German Region } \\
\hline North & Lower Saxony, Schleswig-Holstein, Bremen \\
\hline Mid-West & Hesse, North Rhine Westphalia, Rhineland-Palatine, Saarland \\
\hline East & Brandenburg, Mecklenburg-West-Pomerania, Saxony, Saxony-Anhalt, Thuringia \\
\hline South-East & Bavaria \\
\hline South-West & Baden-Wuerttemberg \\
\hline Metropolis & Hamburg, Berlin \\
\hline Germany (total) & Germany as a whole \\
\hline One EU country & Honey originating in one specific EU country. \\
\hline One non-EU country & Honey originating in one specific country outside the EU. \\
\hline \multicolumn{2}{|l|}{ EU Blend } \\
\hline $\begin{array}{l}\text { Non-EU Blend } \\
\text { EU-non-EU Blend }\end{array}$ & Blend of honey from different origins (outside and inside the EU). \\
\hline \multicolumn{2}{|l|}{ Packaging } \\
\hline Glass & Jar of honey. \\
\hline PET Dispenser & The honey is supplied in a PET Dispenser. \\
\hline Multipack & More than one honey is offered as one packaging (e.g., travel sizes). \\
\hline Other Packaging & Special packaging e.g., gift packaging. \\
\hline
\end{tabular}

Notes. ${ }^{\text {a) }}$ For more detailed information on retailers, see Section III. B.

(Source) Authors' illustration.

\section{B. Database}

The empirical analysis combines prices of four German online food stores: (i) gourmondo.de, (ii) Alnatura-Shop.de, (iii) myTime.de, and (iv) Heimathonig.de, and one German stationary retail store: (v) REWE Center. The dataset consists of 263 honey prices collected in December 2017. Additionally, the database of Krandick (2015) is considered in Section V.B to compare differences in price and assortments in the online market between 2015 and 2017. As both samples consist mainly of the same online shops, the online honey prices are comparable.

The main characteristics of the shop selected can be outlined as follows. REWE Center 
belongs to the REWE Group, and, with 3,300 shops, it is an important food retail store in Germany. REWE Center is a supermarket with a large assortment of different product categories for daily demand (REWE Group, 2019). Gourmondo GmbH was founded in 2002 as an online shop for high-quality foods originating from all over the world (Gourmondo, 2019a). Since 2009, Gourmondo has focused mainly on regional production and organic farming. Consequently, the supply of organically certified products has risen to more than 500 products (Gourmondo, 2019a, 2019b). Comparable to gourmondo.de, the webshop of Alnatura (officially called Alnatura Super Nature Shop) focused mainly on regional production and offered around 900 organic products in 2019 (Alnatura, 2019a). The Alnatura Super Nature Shop arose out of cooperation between the Gourmondo $\mathrm{GmbH}$ and the Alnatura Produktions- und Handels $\mathrm{GmbH}$, which was founded in 1984 (Alnatura, 2019a). Since 2012, the webshop of myTime.de has belonged to the German Bünting E-Commerce GmbH \& Co. KG, and offers over 12,000 food products (Bünting, 2018; myTime, 2019). Moreover, the internet platform Heimathonig.de offers direct sales from German beekeepers to consumers (Heimathonig, 2018).

\section{Statistical evidence on honey prices}

The complete survey consists of 263 honey prices collected in 2017. However, 22 observations are not included in the subsequent analysis because of missing values about the honeys' origin. Despite extensive search, the origin of those 22 different honeys, mostly distributed via AlnaturaShop.de, was not identifiable.

The largest honey assortment was offered by REWE Center, with $n=90$ different honeys. The second-largest honey assortment was available at Heimathonig.de $(n=67)$, followed by myTime.de $(n=42)$, Alnatura-Shop.de $(n=39)$, and gourmondo.de $(n=25)$.

Product prices vary substantially across retail stores, as depicted in Table 2 . This indicates as wide range of different honeys offered in each of the five retail stores. Overall, honeys in our dataset were sold at a mean price of $8.20 € / 500 \mathrm{~g}$. However, myTime.de (mean honey price of $6.23 € / 500 \mathrm{~g}$ ) and REWE Center (the mean honey price of $7.02 € / 500 \mathrm{~g}$ ) offer the cheapest products, whereas gourmondo.de (mean honey price of $12.81 € / 500 \mathrm{~g}$ ) offer the most expensive. gourmondo.de, as well as Alnatura-Shop.de, were specialty shops, characterized by higher product prices and a special philosophy (cf. Alnatura, 2019a, 2019b; Gourmondo, 2019a, 2019b). Apparently, distributors do not compete with the price alone, but also with the product range offered in their shops. 
Table 2. Descriptive Statistics of Prices: Online, Offline and Total $(€ / 500 g)^{a}$

\begin{tabular}{lccccc}
\hline Samples & Mean & Median & Maximum & Minimum & Obsenvations \\
\hline Total Sample & 8.20 & 7.00 & 49.50 & 2.49 & 241 \\
Offline & 7.02 & 6.49 & 18.55 & 2.49 & 90 \\
Online total & 8.91 & 7.90 & 49.50 & 2.89 & 151 \\
Online conventional & 7.78 & 7.50 & 15.65 & 2.89 & 109 \\
\hline Descriptive price statistics of one typical honey brand & 6.28 & 15.10 & 3.99 & 34 \\
\hline Total & 7.00 & 6.28 & 15.10 & 2.36 & 20 \\
Offline & 6.87 & 6.38 & 14.95 & 4.79 & 14 \\
Online total & 7.20 & & & & \\
\hline
\end{tabular}

Notes. ${ }^{\text {a }}$ For the sake of simplicity, the Authors refer to Heimathonig, myTime, Alnatura, and Gourmondo, instead of naming the respective website. Online total lists price statistics in $€ / 500 \mathrm{~g}$ for all online shops of the dataset. Online conventional excludes the two online specialty shops, Alnatura and Gourmondo. Their assortments are very different from that of the stationary market in the underlying sample.

(Source) Authors' calculations.

Given the differential assortments in the four online shops, a price comparison between online and stationary retailing yields consumer prices that are $14.5 \%$ higher in the online stores than in the offline stores. When excluding the two specialty shops, average honey prices (in $€ / 500 \mathrm{~g}$ ) remain $10.8 \%$ higher in online retailing than in the stationary market. When we compare only the prices of a typical honey brand, "Langnese Flotte Biene," the average price markup in online stores becomes smaller, at $+4.9 \%$. We can summarize from these aggregate statistics that online and offline prices for honey are at comparable levels. There is a higher price level online than offline, but it is partly due to a different assortment of products available in specialty online stores. The markup of online prices for identical standard honey is about $5 \%$ less than offline prices.

Table 3 depicts descriptive price statistics (in $€ / 500 \mathrm{~g}$ ) clustered for products with a specific sustainability characteristic. Of all honeys, $9 \%$ in the online sample are certified by the Fairtrade Labelling Organization (FLO) or by GEPA, and even 36\% are organically certified (Bioland or EU-Bio Label). The numbers are lower for stationary retailing (fairtrade: $0 \%$; organic certification: $29 \%$ ). On the contrary, the stationary market provides a home to retail brands, whereas pure online retailing does not. Both might be a reason for higher (mean) online prices compared to the stationary market.

Comparing mean honey prices of different sustainability attributes indicates lower prices for a blend of honey from different European and non-European countries (e.g., honey from different regions in Germany) compared with all honeys from a defined region in Germany, but also from any defined EU or non-EU country. Several honeys with an assignment to a special country of origin (e.g., one EU country, one country outside the EU) realize a price that is above the overall mean retail price of $8.20 € / 500 \mathrm{~g}$, as do some German regions like 
North, South East, South West, or Metropolis. Prices for honeys with certified origins range above the mean honey price. It appears as if another sustainability characteristic, namely packaging (e.g., PET dispenser, glass), does not strongly determine consumer price premiums as multipacks and special gift boxes are priced highest within this category. It should be borne in mind, however, that Table 3 illustrates mean prices for honeys with specific characteristics. Typically, these honeys are combined with quite a number of other characteristics as well. We are more interested in price premiums for certain sustainability characteristics given that other product characteristics are kept constant. This information will be provided in the next section on the basis of the econometric model, in which other price determinants are controlled.

Table 3. Prices of Honeys with Sustainability Characteristics (€/500g)

\begin{tabular}{|c|c|c|c|c|c|}
\hline Variables & Mean & Median & Max. & Min. & Obs. \\
\hline \multicolumn{6}{|l|}{ Fairtrade } \\
\hline GEPA & 6.66 & 6.49 & 9.20 & 4.79 & 9 \\
\hline Fairtrade International & 6.32 & 5.99 & 9.95 & 4.79 & 8 \\
\hline \multicolumn{6}{|l|}{ Organic } \\
\hline Bio-EU & 8.84 & 8.00 & 45.78 & 3.65 & 71 \\
\hline Bioland & 8.97 & 8.40 & 13.00 & 6.49 & 20 \\
\hline \multicolumn{6}{|l|}{ Origin } \\
\hline \multicolumn{6}{|l|}{ German Region: } \\
\hline North & 9.27 & 8.45 & 12.90 & 6.99 & 12 \\
\hline Mid West & 7.48 & 7.20 & 9.90 & 6.40 & 6 \\
\hline East & 7.04 & 6.90 & 9.90 & 5.90 & 9 \\
\hline South East & 9.45 & 8.74 & 14.90 & 7.90 & 16 \\
\hline South West & 9.60 & 9.85 & 12.90 & 6.90 & 8 \\
\hline Metropolis & 8.91 & 8.28 & 15.65 & 6.50 & 26 \\
\hline Germany (total) & 7.73 & 6.79 & 9.98 & 5.79 & 11 \\
\hline One EU Country & 10.89 & 8.99 & 49.50 & 5.98 & 39 \\
\hline One Non-EU Country & 12.24 & 6.49 & 45.78 & 5.49 & 9 \\
\hline EU Blend & 7.44 & 6.70 & 15.10 & 4.99 & 34 \\
\hline Non-EU Blend & 7.16 & 6.11 & 15.10 & 3.65 & 16 \\
\hline EU-Non-EU Blend & 5.89 & 5.79 & 15.10 & 2.49 & 55 \\
\hline \multicolumn{6}{|l|}{ Packaging } \\
\hline Glass & 8.18 & 7.75 & 49.50 & 2.49 & 194 \\
\hline PET Disposer & 6.07 & 5.98 & 8.55 & 3.29 & 33 \\
\hline Multipack & 12.80 & 9.45 & 45.78 & 6.24 & 21 \\
\hline Other Packaging & 13.59 & 9.70 & 45.78 & 6.24 & 14 \\
\hline
\end{tabular}

(Source) Authors' calculations. 


\section{Results of the Econometric Model}

Table 4 shows the estimation results for the empirical model. The regression coefficients of the hedonic pricing model are presented for general product characteristics of the honeys and the defined sustainability characteristics. As the selected model is semilogarithmic and almost all explanatory variables in the hedonic model are dummy variables, the marginal effects of these dummy variables cannot be interpreted (Halvorsen \& Palmquist, 1980).

Therefore, percentage and absolute price effects of adding a certain characteristic to a honey are computed from the regression coefficients, and shown additionally in Table 4. We apply Kennedy's approach to compute the percentage effects of the dummy variables on the dependent variable (Kennedy, 1981). The absolute price effect of adding a dummy variable, which is the implicit price of that characteristic, is computed from the percentage effect.

When implicit prices or the (relative or absolute) price premiums of product characteristics are computed, it is crucial to select a meaningful reference price. We argue that a standard honey on the mass market is a meaningful benchmark. We define the base honey as follows: it is offered by REWE Center and carries a producer's brand name; it is a polyfloral honey without additives and is of liquid (or other than creamy) consistency; and the honey is extracted using common extraction methods, such as by means of a spinning extractor and not by being pressed or scraped. With regard to sustainability characteristics, the honey is produced conventionally (i.e., neither organic nor fairtrade) and traded conventionally (i.e., not fair). The honey is sold in a plastic disposer ( $\mathrm{PET}^{1}$ ) disposer) and is described as blended honey from countries within the EU and non-European nations, without any further regional specification. This reference honey is sold for $4.42 € / 500 \mathrm{~g} .^{2}$ )

1) stands for polyethylene terephthalate and is commonly known as the plastic from which food packaging is made.

2) The price of $4.42 €$ is computed with the hedonic price equation in Table 3 on the basis of the regression constant and the value of 500 grams for the variable $\ln$ (gram) when a zero is plugged in for the dummy variables. 
Table 4. Estimation of a Semilogarithmic Hedonic Price Function

\begin{tabular}{|c|c|c|c|c|c|}
\hline \multirow{2}{*}{$\begin{array}{l}\text { Dependent Variable: Ln(price) } \\
\text { Constant Term }\end{array}$} & \multirow[t]{2}{*}{ Specification } & \multicolumn{2}{|c|}{$\begin{array}{c}\text { Coefficient } \\
\text { (standard error) }\end{array}$} & \multirow[t]{2}{*}{$\begin{array}{l}\text { Price } \\
\text { Effect }^{\text {a) }}\end{array}$} & \multirow[t]{2}{*}{$\begin{array}{l}\text { Implicit } \\
\text { Price }^{\text {b) }}\end{array}$} \\
\hline & & $3.146^{* * *}$ & $(0.172)$ & & \\
\hline \multicolumn{6}{|l|}{ Vendors (V) } \\
\hline \multirow[t]{4}{*}{ Onlineshop (BC: REWE Center) } & gourmondo.de & $0.511 * * *$ & $(0.065)$ & 66.03 & 2.92 \\
\hline & Alnatura-Shop.de & $0.216^{* * *}$ & $(0.063)$ & 25.61 & 1.13 \\
\hline & Heimathonig.de & $0.229(*)$ & $(0.122)$ & 27.19 & 1.20 \\
\hline & myTime.de & -0.055 & $(0.040)$ & - & - \\
\hline \multicolumn{6}{|l|}{ Product Characteristics (PC) } \\
\hline $\operatorname{Ln}($ gram $)$ & & $-0.261 * * *$ & $(0.036)$ & -23.01 & -1.02 \\
\hline Multipack (BC: No Assortment) & Honey Assortment & 0.068 & $(0.103)$ & 6.45 & 0.29 \\
\hline \multirow[t]{3}{*}{ Brand (BC: Packer's Brand) } & D.I.B. & $-0.191(*)$ & $(0.106)$ & -17.84 & -0.79 \\
\hline & Individual Beekeeper & $-0.259 * *$ & $(0.094)$ & -23.16 & -1.02 \\
\hline & Private Label & $-0.169(*)$ & $(0.091)$ & -15.55 & -0.70 \\
\hline Consistency (BC: Liquid \& Other) & Creamy & -0.032 & $(0.034)$ & - & - \\
\hline Additives (BC: No Additives) & Additives & 0.107 & $(0.093)$ & - & - \\
\hline Standard Extraction & Other Method & 0.055 & $(0.094)$ & - & - \\
\hline \multirow[t]{5}{*}{ Type (BC: Blossom Blend) } & Heather & $0.464 * * *$ & $(0.073)$ & 58.65 & 2.59 \\
\hline & Rape & -0.044 & $(0.053)$ & - & - \\
\hline & Fir & $0.455^{* * *}$ & $(0.084)$ & 57.07 & 2.52 \\
\hline & Other Monofloral Blossom & $0.067^{*}$ & $(0.029)$ & 6.88 & 0.30 \\
\hline & Exotic & $0.118^{*}$ & $(0.047)$ & 12.41 & 0.55 \\
\hline \multicolumn{6}{|c|}{ Sustainability Characteristics (SC) } \\
\hline \multirow[t]{2}{*}{ Packaging (BC: PET Dispenser) } & Glass & $0.090(*)$ & $(0.046)$ & 9.31 & 0.41 \\
\hline & Other Package & $0.467 * * *$ & $(0.102)$ & 58.72 & 2.60 \\
\hline \multirow[t]{2}{*}{ Organic (BC: Non-Organic) } & EU Organic Label & $0.068^{*}$ & $(0.036)$ & 6.98 & 0.31 \\
\hline & Bioland Label & $-0.102(*)$ & $(0.058)$ & -9.83 & -0.43 \\
\hline \multirow[t]{2}{*}{ Fairtrade (BC: Non-Fairtrade) } & FLO Label & $0.128\left(^{*}\right)$ & $(0.070)$ & 13.37 & 0.59 \\
\hline & GEPA Label & $-0.569 * * *$ & $(0.126)$ & -43.84 & -1.94 \\
\hline \multirow[t]{11}{*}{ Origin (BC: EU-Non-EU Blend) } & German Region: North & $0.396 * * *$ & $(0.076)$ & 48.14 & 2.13 \\
\hline & German Region: Mid West & $0.336 * * *$ & $(0.091)$ & 39.38 & 1.74 \\
\hline & German Region: East & $0.320 * *$ & $(0.096)$ & 37.09 & 1.64 \\
\hline & German Region: South East & $0.501 * * *$ & $(0.082)$ & 64.46 & 2.85 \\
\hline & German Region: South West & $0.525 * * *$ & $(0.096)$ & 68.29 & 3.02 \\
\hline & German Region: Metropolis & $0.410 * * *$ & $(0.088)$ & 50.08 & 2.21 \\
\hline & Germany (Total) & $0.351 * * *$ & $(0.078)$ & 41.62 & 1.84 \\
\hline & EU Blend & $0.251 * * *$ & $(0.044)$ & 28.40 & 1.26 \\
\hline & Non-EU Blend & 0.018 & $(0.066)$ & - & - \\
\hline & One EU Country & $0.358 * * *$ & $(0.053)$ & 42.83 & 1.89 \\
\hline & One Non-EU Country & $0.483 * * *$ & $(0.148)$ & 60.32 & 2.67 \\
\hline \multicolumn{6}{|c|}{ Test Statistics: $n=241 ;$ Adjusted- $R^{2}=0.740 ; F$-Value $=21.071^{* * *}$} \\
\hline \multicolumn{6}{|c|}{$\begin{array}{l}\text { Notes. } \mathrm{BC}=\text { base category; } * * *,[* *, *,(*)] \text { significantly different from zero at the } 99.9 \%-[99 \%-, 95 \%-,(90 \%-)] \text { level. } \\
\text { a) In semilogarithmic equations, the percentage impact of a dummy variable on the dependent variable is estimated } \\
\text { in } \% \text { according to the Kennedy approach as } 100 *\left(\left(e^{\beta-0.5 \operatorname{Var}(\beta)}\right)-1\right) \text { (Van Garderen and Shah, 2002). } \beta \text { stands } \\
\left.\text { for the regression coefficient, while } \operatorname{Var}(\beta) \text { stands for the variation of the } \beta \text {-coefficient. }{ }^{\circ}\right) \text { Implicit Euro prices } \\
\text { are calculated using the price of a reference honey }(4.42 € / 500 \mathrm{~g}) \text {. Implicit prices are shown only if regression } \\
\text { coefficients are significantly different from zero at the } 90 \% \text {-level at least. }\end{array}$} \\
\hline
\end{tabular}


As depicted in Table 4, the chosen semilogarithmic model has a good model fit, indicated by an adjusted $R^{2}$ of 0.740 and a highly significant F-Statistic. There are many product characteristics of honey, which are important for the explanation of honey prices from a cross-section point of view. Twenty-six of the included explanatory variables are significantly different from zero at the $90 \%$-level or higher.

We can confirm one first general result, which Unnevehr and Gouzou (1998) had elaborated in the 1990s for the U.S. honey market: Consumers in Germany pay substantial premiums for some types of honey based on their floral sources and brands. In the German market, price premiums are extremely strong for monofloral honey, such as heather and fir honey $(+58.7 \%$ and $+57.1 \%$, respectively, compared to the standard honey). Furthermore, packers' brands realize higher prices for these honeys than the honeys certified by D.I.B., individual beekeepers, or private labels.

Moreover, estimation results underline the main findings of the descriptive price analysis saying that honey sold by Alnatura-Shop.de, Gourmondo.de, and Heimathonig.de was more expensive than honey sold by the stationary supermarket (REWE Center). Those results are significant between the $90 \%$ - and $99 \%$-significance levels and indicate a positive price markup for retail shops with a focus on regional and organic production (Gourmondo, Alnatura, Heimathonig) of between 1.13 and $2.92 € / 500 \mathrm{~g}$.

Our main interest here, however, is how sustainability characteristics affect honey prices. The computations shown in Table 4 suggest that the regional origin of the honeys outperforms all other sustainability characteristics in terms of consumer price premiums. Ceteris paribus, a defined regional origin in Germany or a certain region in Germany raises the consumer price between $37.1 \%$ (East) and $64.5 \%$ (South East) compared to the EU-Non-EU Blend. The consumer price premium is $41.6 \%$ for Germany and $50.1 \%$ for honey from a German major city (e.g., Berlin and Hamburg). Interestingly, honey produced in a defined other country of the EU (One EU Country) or outside the EU (One Non-EU Country $\left.{ }^{3}\right)$ ) also realizes a high consumer price premium, $+42.8 \%$ and $+60.3 \%$, respectively, compared to the EU-Non-EU Blend.

There are price premiums for other sustainability characteristics, too, but they are much lower than for other characteristics. Glass packaging, the EU organic label and the FLO label (compared to the PET dispenser, the non-organic, and the non-fairtrade honey, respectively) are cases in point.

On the other hand, there are cases for which the expected positive price effect of an organic or a fairtrade label does not exist. This holds true for the Bioland as well as the GEPA label. It has to be borne in mind that, in this context, certified honeys will be associated with other characteristics that are covered separately. Therefore, the certification captures the additional

3) Origins included in this variable are, for example, Australia, Mexico, and Nicaragua. 
reputation of the label when the product's quality characteristics are controlled.

\section{Discussion}

Our analysis shows the particular role of the regional origin of honeys for the consumer price in the German market, using data for 2017. How can these high consumer premiums for regional origin be explained, and what follows from the observed price premiums for foreign suppliers in international honey trade? This is now discussed along with the question about how the presented premiums are affected (i) by the time period chosen, and (ii) when online and offline data are compared.

\section{A. How do we explain the high consumer price premiums for the honeys with regional origin information?}

One possible explanation for high consumer price premiums for the honey with regional origin information is the major general trend toward regional and even local products in food consumption (Adalja, 2015). Surveys of consumers indicate that environmental concerns are one reason behind this trend. Consumers perceive products from their own region as being environmentally friendly since transport costs are saved and "food miles" reduced (Thilmany et al., 2008). In surveys of honey consumers, environmental benefits of this type have been stressed for the U.S. (Wu et al., 2015) as well as for Italy, where the preference for the domestic origin is strong (Cosmina et al., 2016).

There are other possible reasons for consumer perceptions in favor of foods from their own region. The consumption of regional products may be seen as a vehicle to support the regional economy; Wu et al. (2015) reported that the U.S. honey consumers strongly support this view.

Further arguments for a preference toward regional honey are based on food-safety considerations. Apart from increased threats of the honey economy due to the increased spread of bee diseases, food fraud has risen significantly due to honey adulteration (García, 2018) and honey laundering (Ritten et al., 2019). The international honey market has been widely discussed in the media as one of the main target markets for food fraud. Recent empirical evidence showed that information about honey laundering raised the willingness to pay for the local producers who can guarantee a fraud-free production (Ritten et al., 2019). It is reasonable for consumers to consider regional or domestic honey, or honey from countries with an established reputation, as a kind of insurance against health risks from fraud. We have not analyzed explicitly which of these possible reasons might have led to the observed high price premiums for defined regional origins. However, there are indications in the econometric results that rather point 
to the special importance of food-safety concerns:

(i) There is a higher marginal willingness to pay for clear regional origins compared to the reference product of blended honey from EU and non-EU sources.

(ii) Regional origins with consumer price premiums are not only German regions or Germany as a whole, but also other EU countries or certain non-EU countries with a known reputation. This suggests that it is more the food-safety argument rather than environmental concerns or the support of the domestic economy that governs consumers' perceptions of the German honey market.

\section{B. The intemational dimension of price premiums for origin in the German honey market}

Some interesting lessons can be learned for international honey trade, particularly regarding foreign suppliers. The origin coefficients of the hedonic price model suggest that the options of exporting countries differ substantially depending on the collective reputation of the respective country's honey sector.

There is a positive marginal willingness to pay in the German honey market for domestic products, as the positive and statistically significant coefficients of the German origin variables show. Apparently, domestic producers have a positive reputation with which foreign suppliers have to compete. Three options are available for exporters to the German market:

1. Individual exporting countries, which have a reputation for high quality, may also gain from consumer price premiums for origins. Such collective reputation does exist on the German honey market for honey, as the positive and statistically significant coefficients of One EU country or One Non-EU country show. These foreign exporters will be able to serve the higher-quality segment of the German market as well as its domestic competitors. Examples include Spain as an EU country, and New Zealand and Mexico as non-EU countries. All three countries offer specialties, such as Spain's orange blossom honey, New Zealand's Mantuka honey, and Mexico's Yucatan honey, and all three realize import unit values that are well above the average. Moreover, Spain and Mexico had considerable value shares of the German import market at $7.8 \%$ and $14.0 \%$, respectively, in 2017 (FAO, 2020b).

2. There are other foreign exporters who have not, or not yet, reached the status of receiving a consumer price premium for their country of origin. These exporters do not serve the German honey market with single-origin honeys. They instead deliver their honey for blended products. As the positive and statistically significant coefficient of the EU blend variable and the insignificant coefficient of the non-EU blend variable indicate, EU countries have a stronger position in this exporter group than non-EU exporters. They 
can reach consumer prices that are above the price of the mass market by selling parts of their honey in an EU blend. Examples include Hungary and Poland.

3. Foreign countries who have not reached the status of getting a quality premium for the regional origin have the option to participate in the mass market by delivering to processors who offer non-EU blends or EU-non-EU blends. Exporters in this group may increase their market share by investing in quality production and their reputation. For example, the Ukraine reached a sizeable share of the German import market in $2017-12.9 \%$ in quantity terms and $7.4 \%$ in value terms. However, countries with an image of low-quality in this group are at a risk of losing market shares even in the mass market after food-fraud cases. This holds true for China, which has been involved in several honey-fraud cases (Ritten et al., 2019) and realized the lowest import unit value of the large non-EU exporters between 2015 and 2018 (European Commission, 2020). In fact, in the German honey import market, China captured only a value share of $2.8 \%$ and a quantity share of $4.5 \%$, despite its major share of the world market (FAO, 2020b).

\section{Are the findings on implicit prices of sustainability stable over time?}

Honey supply varies significantly every year in terms of magnitude and structure, thus the question about how the respective market situation affects the price premiums for honey characteristics arises. Are those premiums stable across different periods and, thus, are the major model results reliable? For a robustness check of the model, we compared our price premium for 2017 with those in a recent study from Bissinger et al. (2019), in which a pure online database was used.

The two years differ strongly with regard to the situation on the international honey market. Before 2015, international honey prices had been rather stable for about six years. The EU average unit value for imported honey, which can be seen as an indicator of the world market situation, was $1.93 € / \mathrm{kg}$ in 2009 . It rose continuously to $2.08 € / \mathrm{kg}$ in 2011 and 2012 , fell slowly to $2.04 € / \mathrm{kg}$ in 2013 , and increased again to $2.14 € / \mathrm{kg}$ in 2014 . Subsequently, the international price increased sharply to $2.52 € / \mathrm{kg}$ in 2015 . After 2015 , the international price fell sharply to $2.17 € / \mathrm{kg}$ in 2017 . Given the high share of imported honey in the German honey market, it can be expected that these strong world market effects affected German honey prices. This is confirmed by aggregate consumer price statistics for Germany. Although the percentage changes are much less than on the international market, consumer prices for honey increased significantly in 2015 and fell by less in 2017 ( $+7.0 \%$ and $-2.5 \%$, respectively, compared to the previous year).

Despite the difference between the particularly high price level in 2015 and the clearly lower level in 2017, the consumer price premiums for honeys with a defined regional origin are very 
similar between the study by Bissinger et al. (2019; Table 2) and the present work (see Table 3):

1. The median of the percentage price effects of the defined regions within Germany or for total Germany in Bissinger et al. (2019) is $48.1 \%$ for 2015 , and is $39.1 \%$ in our study for 2017.

2. The median of the absolute price effects of the defined German regions is $2.21 € / 500 \mathrm{~g}$ in 2015 , and is $1.88 € / 500$ grams for 2017 .

3. The consumer price premiums for honeys with a defined country origin outside Germany are also similar. Bissinger et al. (2019) computed a price premium of $42.6 \%$ with their 2015 online data for the variable foreign country. In our econometric specification, we disaggregate the individual foreign country into One EU country and One Non-EU country. The price premiums are generally high, with a very similar magnitude for the individual EU country (42.8\%) and even higher for the individual non-EU country (60.3\%).

We can summarize that the market situation in the international and the domestic honey market may alter price premiums for honey characteristics. Surprisingly, the consumer price premiums for clarified regions of origin compared to the standardized blended honey are very similar for two different years. The hedonic analysis yields very stable results.

\section{Is the online market different from the offline market for honey?}

It is often questioned whether the data are representative for (offline) food markets as the online market has a high growth rate but a rather low market share. On the basis of our results, we can conclude that prices on online markets are similar to offline prices. The recent literature on online pricing indicated that foods tend to be priced higher online than in brick-and-mortar stores (Fedoseeva et al., 2017). This was also confirmed for honey in Table 2. However, the price differential diminished strongly when two suppliers that concentrated more on selling specialties were excluded. Moreover, average prices for identical standard honey ranged only by about $3 \%$ above the price in offline stores. Therefore, future studies should consider differential assortment strategies of online retailers that may be responsible for a rather large part of price differentials regarding the overall price levels online and offline.

The comparison between our 2017 online data and the sample of 2015 used by Bissinger et al. (2019) reveals an additional interesting aspect related to the honeys offered and the prices set in online retailing. Price differences from 2015 to 2017 were minor in an overall comparison of mean product prices. Figure 2 depicts the distribution of honey prices for 2015 (black) and 2017 (gray). It is shown that most honeys were sold in the range of 4-12 $€ / 500 \mathrm{~g}$ in 2015 and 2017. German honey was sold in the mean for around $9 € / 500 \mathrm{~g}$ in both years $(2015: 8.8 € / 500 \mathrm{~g}$; 2017: $8.9 € / 500 \mathrm{~g})$. 
Figure 2. Distribution of (online) honey prices $(€ / 500 \mathrm{~g})$ in 2015 and 2017

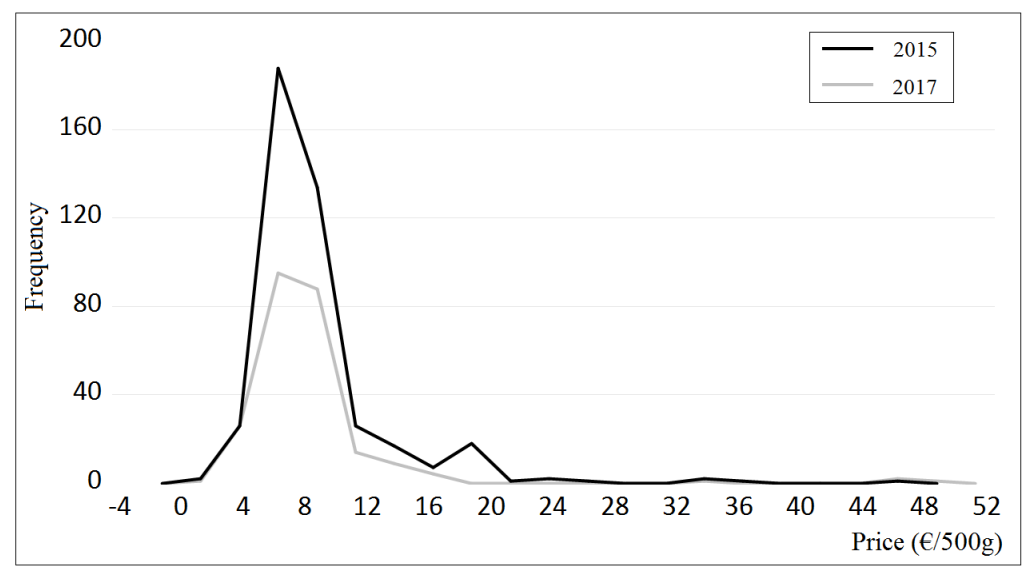

Notes. To identify the distribution of prices within one single figure, the polygon shape of a histogram is used.

(Source) Authors' illustration.

However, it is striking that the honey assortments of online retailers differed substantially between 2015 and 2017. Online retailers tend to combine rather stable prices for honeys that are continuously available with a high variation of the available range of honeys. Respectively, the number of honeys being distributed online (nearly) halved in $2017\left(N_{2017 \text { online }}=151\right)$ in direct comparison to $2015\left(N_{2015}=426\right)$. Moreover, the product-mix offered in the four online shops changed significantly: the share of German honey being distributed online decreased (2015: 67.8\%; 2017: 33.1\%), while the share of blended honey made within the EU (2015: 5.6\%; 2017: 24.5\%) and the share of exotic honey being distributed online increased (2015: 6.3\%; 2017: 17.2\%). According to a random check of the four online distributors in January 2019, the assortments were adjusted again.

These findings are in line with the marketing literature, stating that variations in assortment over time are an essential determinant of the shop's success as it fundamentally influences the consumers' buying behavior (Groß, 2013; Hart, 1999). One of the main advantages of online retailing might be the adjustment costs being lower than those in the stationary market. Therefore, it appears that adjustments in the variety of the product range are an attractive alternative to price changes if customers are less antagonized by assortment than price changes. This is an interesting case of nonprice competition as an explanation of price stickiness (Blinder et al., 1998).

Moreover, honey assortments in the stationary market were deeper and broader than in online retailing. This somehow contradicts former research on the product range in online retailing (e.g., Bhatnagar and Syam, 2014; Dukes et al., 2009; Grewal et al., 2010; Li et al., 2015), saying that the product range is larger in online retailing than in the stationary market. 


\section{Conclusions}

In a quantitative analysis based on German online and offline price data for honey, we examine how general and sustainability characteristics of honey affect honey prices. The following are the major findings. Product differentiation on the German market for honey is high. Hedonic price analysis reveals that many characteristics lead to a consumer price premium compared to a standard honey on the mass market. Consumer price premiums are high, such as for some monofloral honeys like heather and fir honey, and certain brands. Among the sustainability characteristics, fairtrade certification, organic production, the regional origin as well as environmentally friendly packaging were included. A striking result is that a clearly identified regional origin outperformed all other sustainability characteristics in terms of the size of the consumer price premium. This main result remains valid at different points of time and in online as well as offline data. The hedonic model suggests that consumers' food-safety concerns are more important for the high price premium than are environmental issues or the wish to support domestic producers.

Our analysis raises some general questions for future research that reach beyond the honey case. The question arises whether there is a general pattern behind the consumer price premium of sustainability characteristics across different foods. It might be that the consumer price premium for organic production is generally lower in food markets where consumers perceive the product as a natural one, as in the honey case. It might also occur that the consumer price premium for fairtrade certification is generally lower in markets like honey, where production from the own region competes with the supply from developing countries. In addition, food-safety concerns might generally drive up the consumer price premium for reliable regional origins in food markets for which food fraud is widespread. Further research along these lines in other markets appears worthwhile.

An interesting observation is that the assortment of online traders varies more under market shocks than the price of the core products. The question arises whether this honey-specific result is also valid for other foods. If so, this could imply that prices are rather sticky in online markets, too, and changes of the available products are regarded as a substitute for price changes.

There are also some limitations of our approach that might be covered in further studies with other methods:

1. We derive our conclusion that food-safety concerns may be the dominating demand-side argument for the price premium of regional-origin variables from the reduced form hedonic model. Consumer surveys could help to put the result into perspective.

2. Between the sustainability indicators, consumer price premiums may also vary due to different marginal costs of supplying those characteristics. A structural supply and demand model for honey can provide additional insights if data on quantities and marginal costs become available. 


\section{References}

Adalja, A. (2015). An examination of consumer willingness to pay for local products. Agricultural and Resource Economics Review, 44(3), 253-274.

Alnatura Super Nature Shop (Alnatura). (2019a). Über Alnatura Shop. Retrieved from https://www.alnatura -shop.de/aboutShop (accessed 26 July 2019).

Alnatura Super Nature Shop (Alnatura). (2019b). Alnatura Philosophie- Die Alnatura Ideale. Retrieved from https://www.alnatura-shop.de/our-philosophie (accessed 26 July 2019).

Bhatnagar, A., \& Syam, S. S. (2014). Allocating a hybrid retailer's assortment across retail stores: Bricks-and-mortar vs online. Journal of Business Research, 67, 1293-1302.

Bioland e.V. (Bioland) (2020). Sieben Prinzipien für die Landwirtschaft in der Zukunft. Retrieved from https://www.bioland.de/ueber-uns/sieben-prinzipien.html (accessed 25 March 2020).

Bissinger, K., Herrmann, R., \& Krandick, L. (2019). Implicit Prices of Sustainability on the German Online Market for Honey. German Journal of Agricultural Economics, 68(3), 178-194.

Blinder, A. S., Canetti, E. R. D., Lebow D. E., \& Rudd, J. B. (1998). Asking About Prices. A New Approach to Understanding Price Stickiness. New York: Russell Stage Foundation.

Bundesministerium für Ernährung und Landwirtschaft (BMEL) (2020). EU-Bio-Label. Retrieved from https://www.bmel.de/DE/Landwirtschaft/Nachhaltige-Landnutzung/Oekolandbau/_Texte/EU-Bio-Logo .html (accessed 25 March 2020).

Bünting Unternehmensgruppe (Bünting). (2018). Der Lebensmittel-Online-Supermarkt. Retrieved from https://www.buenting.de/gesellschaften/buenting-e-commerce/mytimede.html (accessed 12 April 2019).

Cosmina, M., Gallenti, G., Marangon, F., \& Troiano, S. (2016). Attitudes towards honey among Italian consumers: A choice experiment approach. Appetite, 106, 110-116.

Cranfield, J., Deaton, B. J., \& Shellikeri, S. (2009). Evaluating consumer preferences for organic food production standards. Canadian Journal of Agricultural Economics, 57(1), 99-117.

Deutscher Imkerbund e.V. (DIB) (2019). Der DIB stellt sich vor: Gemeinsame Ziele-gemeinsames Handeln. Retrieved from https://deutscherimkerbund.de/155-Gemeinsame_Ziele___Gemeinsames_Handeln (accessed 26 March 2020).

Didier, T., \& Lucie, S. (2008). Measuring the willingness to pay for organic and fair trade products. International Journal of Consumer Studies, 32(5), 479-490.

Dukes, A. J., Geylani, T., \& Srinivasan, K. (2009). Strategic assortment reduction by a dominant retailer. Marketing Science, 28(2), 309-319.

European Commission. (2020). Honey Market Presentation, Agriculture and Rural Development. Retrieved from https://ec.europa.eu/agriculture/sites/agriculture/files/honey/market-presentation-honey_en.pdf (accessed 31 May 2020).

Fairtrade International (2020). Was ist Fairtrade? Retrieved from https://www.fairtrade.net/about/what-is-fai rtrade (accessed 25 March 2020).

Fedoseeva, S., Herrmann, R., \& Nickolaus, K. (2017). Was the economics of information wrong all the way? Evidence from German grocery r(E)tailing. Journal of Business Research, 80, 63-72.

FAO (Food and Agricultural Organization of the United States) (2020a). Chapter 6 Colony manipulation: 
honey and beeswax harvesting and extraction. Retrieved from http://www.fao.org/3/t0104e/T0104E0a.htm (accessed 26 March 2020).

FAO (Food and Agricultural Organization of the United States). (2020b). FAOSTAT Rome. Retrieved from http://www.fao.org/faostat/en

García, N. L. (2018). The Current Situation on the International Honey Market. Bee World, 95(3), 89-94.

GEPA (Gesellschaft zur Förderung der Partnerschaft mit der Dritten Welt GmbH) (2020). Gepa-Kriterien für Fairen Handel. Retrieved from https://www.gepa.de/gepa/mission/gepa-kriterien.html (accessed 25 March 2020).

Gourmondo GmbH (Gourmondo). (2019a). Unternehmensgeschichte. Retrieved from https://www.gourmon do.de/company-history (accessed 26 July 2019).

Gourmondo GmbH (Gourmondo). (2019b). Bio-Zertifikate und Slow-Food. Retrieved from https://www.go urmondo.de/bio-certificate (accessed 28 August 2018).

Grewal, D., R. Janakiraman, K. Kalyanam, P. K. Kannan, B. Ratchford, Song R., \& Tolerico., S. (2010). Strategic Online and Offline Retail Pricing: A Review and Research Agenda. Journal of Interactive Marketing, 24, 138-154.

Groß, S. (eBusiness-Lotse Köln) (2013). Einflussfaktoren im E-Commerce: Die Anforderungen der Online-Shopper heute und morgen - Ein Leitfaden für kleinere und mittlere Unternehmen, Mittelstand Digital, Gefördert durch das Bundesministerium für Wirtschaft und Technologie. Retrieved from http://www.ebusinesslotseostbrandenburg.de/elo-wAssets/docs/Online-Marketing/Leitfaden_Erfolgsfaktoren-im-E-Commerce.pdf (accessed 29 January 2019).

Halvorsen, R., \& Palmquist, R. (1980). The Interpretation of Dummy Variables in Semilogarithmic Equations. The American Economic Review, 70(3), 474-475.

Hart, C. (1999). The Retail Accordion and Assortment Strategies: An Exploratory Study. The International Review of Retail, Distribution and Consumer Research, 9(2), 111-126.

Heimathonig (Heimathonig.de). (2018). Willkommen bei Heimathonig-Honig direkt vom Imker. Retrieved from https://www.heimathonig.de/ (accessed 28 August 2019).

Jensen, J. D., \& Mørkbak, M. R. (2013). Role of gastronomic, externality and feasibility attributes in consumer demand for organic and local foods: The case of honey and apples. International Journal of Consumer Studies, 37(6), 634-641.

Kennedy, P. E. (1981). Estimation with Correctly Interpreted Variables in Semilogarithmic Equations. The American Economic Review, 71(4), 801.

Krandick, L. (2015). Spiegeln sich Nachhaltigkeitskriterien von Lebensmitteln im Produktpreis: Ergebnisse einer hedonischen Analyse für Honig mit Daten aus Online-Shops. (Arbeitsbericht Nr. 63). Institut für Agrarpolitik und Marktforschung, Gießen.

Lans, I. A. van der, Ittersum, K. van, De Cicco, A., \& Loseby, M. (2001). The role of the region of origin and EU certificates of origin in consumer evaluation of food products. European Review of Agricultural Economics, 28(4), 451-477.

Li, Z. E., Lu, Q., \& Talebian, M. (2015). Online versus Bricks-and-mortar Retailing: A Comparison of Price, Assortment and Delivery Time. International Journal of Production Research, 53(13), 3823-3835. 
myTime. (2019). Ihre Vorteile auf einen Blick. Retrieved from https://www.mytime.de/ (accessed 26 July 2019).

Pelsmacker, P. de, Driesen, L., \& Rayp, G. (2005). Do consumers care about ethics? Willingness to pay for fair-trade coffee. Journal of Consumer Affairs, 39(2), 363-385.

REWE Group. (2019). REWE Group Weltweit. Retrieved from https://www.rewe-group.com/de/unternehm er/vertriebslinie (accessed 26 July 2019).

Ritten, C.J., Thunström, L., Ehmke, M., Beiermann, J., \& McLeod, D. (2019). International honey laundering and consumer willingness to pay a premium for local honey: An experimental study. Australian Journal of Agricultural and Resource Economics, 63(4), 726-741.

Rosen, S. (1974). Hedonic prices and implicit markets: product differentiation in pure competition. Journal of Political Economy, 82(1), 34-55.

Schollenberg, L. (2012). Estimating the hedonic price for fair trade coffee in Sweden. British Food Journal, 114, 428-446.

Schröck, R. (2014). Valuing country of origin and organic claim: A hedonic analysis of cheese purchases of German households. British Food Journal, 116(7), 1070-1091.

Sexton, R. J. (2013). Market Power, Misconceptions, and Modern Agricultural Markets. American Journal of Agricultural Economics, 95(2), 209-219.

Thilmany, D., Bond, C. A., \& Bond, J. K. (2008). Going local: Exploring consumer behavior and motivations for direct food purchases. American Journal of Agricultural Economics, 90(5), 1303-1309.

Unnevehr, L. J., \& Gouzou, F. C. (1998). Retail Premiums for Honey Characteristics. Agribusiness, 14(1), 49-54.

Van Garderen, K. J., \& Shah, C. (2002). Exact interpretation of dummy variables in semilogarithmic equations. The Econometrics Journal, 5(1), 149-159.

Wu, S., Fooks, J., Messer, K. D., \& Delaney, D. (2015). Consumer demand for local honey: An artefactual field experiment. Applied Economics, 47(41), 4377-4394. 